\title{
Role of Polysaccharides in Complex Mixtures with Soy Protein Hydrolysate on Foaming Properties Studied by Response Surface Methodology
}

\author{
Karina D. Martínez and Ana M. R. Pilosof \\ Departamento de Industrias, Facultad de Ciencias Exactas y Naturales, Universidad de Buenos Aires, Ciudad Universitaria, \\ 1428 Buenos Aires, Argentina \\ Correspondence should be addressed to Karina D. Martínez; karinadafnem@yahoo.com.ar
}

Received 28 June 2013; Revised 9 December 2013; Accepted 10 December 2013; Published 4 February 2014

Academic Editor: Vladimir Kren

Copyright (c) 2014 K. D. Martínez and A. M. R. Pilosof. This is an open access article distributed under the Creative Commons Attribution License, which permits unrestricted use, distribution, and reproduction in any medium, provided the original work is properly cited.

\begin{abstract}
The complex mixture studied, a hydrolyzed soy protein (HSP), $\kappa$-carrageenan $(\kappa \mathrm{C})$, and an hydroxypropyl methylcellulose (HPMC), could be used as a foaming agent under refrigeration or heating conditions because of the presence of one polysaccharide (HPMC) that gels on heating and another $(\kappa \mathrm{C})$ that gels on cooling. The objective of this work was to study the role of these polysaccharides on foaming properties by whipping methods at heating conditions. For this purpose, response surface methodology was used to optimize the mixed product in foamed food systems. The obtained results showed that the combination of E4M, $\kappa \mathrm{C}$, and HSP is an adequate strategy to generate good foam capacity and stability at heating conditions. The huge stability increase of foams at heating conditions was ascribed to combined effect of polysaccharides: gelling property of E4M and the viscozieng character imparted by $\kappa \mathrm{C}$ to continuous phase of foaming.
\end{abstract}

\section{Introduction}

Soybean proteins are widely used in many foods as functional and nutritional ingredients [1].

Native soy protein, because of its compact tertiary structure, has limited foaming [2-5] and emulsifying [6-8] properties. Structural modifications allowing for greater conformational flexibility of protein may improve their ability to stabilize foams and emulsions. Many studies have demonstrated that the enzymatic hydrolysis of soy proteins improves their functional properties, including solubility, emulsifying, and foaming characteristics [9-11]. Nevertheless, it has been reported that limited hydrolysis may improve foaming capacity but decrease foam stability [12-15]. Therefore, their use would require the addition of polysaccharides as stabilizers. Most high-molecular weight polysaccharides, being hydrophilic, do not have much of tendency for adsorpation at the air-water interface, but they can strongly enhance the stability of protein foams by acting as thickening or gelling agents [16]. However, these gelling properties would change as temperature increases or decreases conforming cooking process. As a result, an adequate hydrolyzed soy protein-polysaccharides mixed system in an appropriate concentration would be useful to achieve acceptable foaming properties. So, a HPMC with gelling capacity on heating conditions and $\kappa \mathrm{C}$ with gelling properties on cooling ones were selected. Thus, the mixed system could be produced and used on heating or cooling treatments.

In a previous work, we study the rheology, through elastic component $\left(\mathrm{G}^{\prime}\right)$ and relative viscoelasticity $(\tan \delta)$ and thermal transitions of continuous phase of the same systems to determine their behavior at $70^{\circ} \mathrm{C}$. It was concluded that E4M was the principal component which determines the elastic and viscoelastic characteristics of complex mixture at $70^{\circ} \mathrm{C}$, due to the gelled structure produced at heating. However, the presence of high hydrolyzed soy protein and/or $\kappa \mathrm{C}$ concentration would inhibit the E4M gel formation which resulted in a low $\mathrm{G}^{\prime}$ and high $\tan \delta$ values. On the basis of these results, we intend to associate them with the foaming properties at $70^{\circ} \mathrm{C}$. 
The system studied in the current work involves these biopolymers, with changes of concentration according to the Doehlert matrix [17] used as experimental design. Hot temperature was selected $\left(70^{\circ} \mathrm{C}\right)$ to simulate heating treatments and study the behavior of the system foamed.

Accordingly, an optimizing method was used to study the role of these polysaccharides on foaming properties by whipping methods at heating conditions.

\section{Materials and Methods}

2.1. Materials. A commercial soy protein isolate (SP) $(90 \%$ protein) from Sanbra, Brazil, was used as substrate for the hydrolysis with fungal protease from Aspergillus oryzae with endopeptidase activity, provided by Quest International. The protein isolate was denatured as detected by differential scanning calorimetry. The following polysaccharides (PS), from Sanofi Bio-Industries, Argentina, were used without further purification: $\kappa$-carrageenan $\kappa \mathrm{C}$ and a hydroxypropyl methylcellulose (HPMC) called E4M from Dow Chemical Co.

2.2. Enzymatic Hydrolysis. SP isolate $(72 \mathrm{~g}$ in $1.200 \mathrm{~mL}$ of water) was hydrolyzed according to Zylberman and Pilosof [18] batchwise by treatment with fungal protease at $\mathrm{pH} 7,50^{\circ} \mathrm{C}$ for $1 \mathrm{~h}$, with enzyme/substrate (E/S) ratio: 2/100. Hydrolysis was stopped by heating at $80^{\circ} \mathrm{C}$ for $10 \mathrm{~min}$.

The variation in $\mathrm{pH}$ was very small (maximum decrease $0.3 \mathrm{pH}$ units) and was adjusted back to the original value with diluted $\mathrm{NaOH}$. Hydrolysates were lyophilized.

The degree of hydrolysis (DH), defined as the percentage of peptide bonds cleaved, was calculated from the determination of free amino groups by reaction with $o$-phthaldialdehyde (OPA) according to Church et al. [19]. Protein hydrolysate with $4 \% \mathrm{DH}$ (HSP) was obtained.

\subsection{Foaming Properties}

2.3.1. Foam Formation. $20 \mathrm{~mL}$ of solutions was foamed at $60^{\circ} \mathrm{C}$, where $\kappa \mathrm{C}$ was not gelled [20], in a graduated tube $(3 \mathrm{~cm}$ diameter) for 3 min with Griffin \& George stirrer at $2500 \mathrm{rpm}$. Overrun was calculated as follows:

$$
\mathrm{FO}(\%)=\left[\frac{\text { foam volume }-20}{20}\right] 100 .
$$

The data reported are means of at least two replicates. The error was less than $10 \%$.

2.3.2. Foam Drainage and Collapse. After foaming production, the stability of foams simulating cooking process was studied by increasing the temperature at $70^{\circ} \mathrm{C}$. The stability against liquid drainage and collapse of height of foams at these conditions was recorded.

The liquid drainage was evaluated as the time to start the foam drainage (lag time to drainage, $\min$ ) and the time required to drainage $20 \%$. This drainage rate $\left(k_{\mathrm{dr}}, \mathrm{min}^{-1}\right)$ was calculated as $1 /$ time.
The foam collapse was calculated as the time required to start the collapse (lag time to collapse, min) and the time required to decrease in $2 \mathrm{~mL}$ the height of the initial foam (collapse time $2 \mathrm{~mL}$, $\mathrm{min}$ ).

The data reported are means of at least two replicates. The relative error for every measure was less than $10 \%$.

2.4. Experimental Design. The combined effect of a hydrolyzed soy protein $(4 \% \mathrm{DH})$, a hydroxyprpyl methylcellulose called E4M and $\kappa$-carrageenan concentrations, on foaming properties was evaluated by response surface methodology. A Dohelert design was selected to elaborate the experiment, which is associated with second-order models detecting optimum values and interactions [17]. This experiment involved 3 factors as independent variables where $x_{1}=$ HSP, $x_{2}=E 4 \mathrm{M}$ and $x_{3}=\kappa \mathrm{C}$ with 7,5 , and 3 levels of concentrations, respectively. The concentrations used were 2 to $10 \% \mathrm{wt} / \mathrm{wt}$ for HSP, 0.2 to $1.8 \% \mathrm{wt} / \mathrm{wt}$ for $\mathrm{E} 4 \mathrm{M}$, and 0.2 to $1.8 \% \mathrm{wt} / \mathrm{wt}$ for $\kappa \mathrm{C}$.

The responses or dependent variables evaluated were the foam overrun at $60^{\circ} \mathrm{C}(\mathrm{FO})$, the foaming stability properties at heating conditions as liquid drainage: lag time to start the foam drainage (lag time to drainage) and their rate $\left(K_{\mathrm{dr}}\right)$, and collapse foams properties: lag time to start foam collapse (lag time to collapse) and the time for the collapse of $2 \mathrm{~mL}$ of their initial height (collapse time $2 \mathrm{~mL}$ ).

A second-degree polynomial model was fitted for each dependent variable as follows:

$$
\begin{aligned}
Y= & b o+b_{1} x_{1}+b_{2} x_{2}+b_{3} x_{3}+b_{4} x_{1}^{2}+b_{5} x_{2}^{2}+b_{6} x_{3}^{2} \\
& +b_{7} x_{1} x_{2}+b_{8} x_{1} x_{3}+b_{9} x_{2} x_{3},
\end{aligned}
$$

where $Y$ is the corresponding dependent variable; bo, bii, and $b i j$ are regression coefficients, and $x i$ denotes the coded independent variables, linearly related to HSP, E4M, and $\kappa \mathrm{C}$ levels.

The real and coded levels of the independent variables used in the experiment design are shown in Table 1.

2.5. Statistical Analysis. The model goodness-of-fit was evaluated by the coefficient of determination $\left(R^{2}\right)$ and the analysis of variance (ANOVA). The response surface and contour plots were developed using the polynomial equations, obtained by holding one of the independent variables at a constant value (at the central point) and changing the levels of the other two variables using Statgraphics Plus 3.0. software.

\section{Results and Discussion}

3.1. Foaming Properties at Heating Conditions. Table 2 shows the results corresponding to foaming properties obtained for all combinations studied at heating $\left(70^{\circ} \mathrm{C}\right)$. It can be seen that $\mathrm{FO}$ value was inversely related to $\kappa \mathrm{C}$ concentration in all $\mathrm{EP}$ (see also Table 1).

$\kappa \mathrm{C}$ addition limited the air incorporation due to the high viscosity imparted during the foam formation. A similar behavior for foams of soy proteins in the presence of xanthan gum has been reported [21]. 
TABLE 1: Experimental matrix: real and coded (in brackets) values for the studied variables.

\begin{tabular}{lccc}
\hline EP & HSP (wt/wt) & E4M (wt/wt) & $\kappa C(w t / w t)$ \\
\hline 1 & $6(0)$ & $1(0)$ & $1(0)$ \\
2 & $6(0)$ & $1.8(1)$ & $1(0)$ \\
3 & $6(0)$ & $0.2(-1)$ & $1(0)$ \\
4 & $10(0.866)$ & $1.4(0.5)$ & $1(0)$ \\
5 & $2(-0.866)$ & $0.6(-0.5)$ & $1(0)$ \\
6 & $2(-0.866)$ & $1.4(0.5)$ & $1(0)$ \\
7 & $10(0.866)$ & $0.6(-0.5)$ & $1.8(0.8165)$ \\
8 & $7.33(0.283)$ & $1.4(0.5)$ & $0.2(-0.8165)$ \\
9 & $4.67(-0.283)$ & $0.6(-0.5)$ & $0.2(-0.8165)$ \\
10 & $4.67(-0.283)$ & $1.4(0.5)$ & $0.2(-0.8165)$ \\
11 & $8.67(0.567)$ & $1(0)$ & $1.8(0.8165)$ \\
12 & $7.33(0.283)$ & $0.6(-0.5)$ & $1.8(0.8165)$ \\
13 & $3.33(-0.567)$ & $1(0)$ & $1(0)$ \\
14 & $6(0)$ & $1(0)$ & $1(0)$ \\
15 & $6(0)$ & $1(0)$ & \\
\hline
\end{tabular}

EP: experimental point; HSP: hydrolyzed soy protein $(4 \% \mathrm{DH})$, E4M: hydroxypropyl methylcellulose; $\kappa \mathrm{C}$ : kappa carrageenan.

TABLE 2: Experimental points (EP) and the corresponding results obtained for foaming properties at heating conditions $\left(70^{\circ} \mathrm{C}\right)$.

\begin{tabular}{|c|c|c|c|c|c|}
\hline EP & $\mathrm{FO}(\%)^{*}$ & $\begin{array}{l}\text { Lag time drain. } \\
(\min )^{*}\end{array}$ & $K_{\mathrm{dr}}\left(\min ^{-1}\right)^{*}$ & $\begin{array}{l}\text { Lag time to collapse } \\
\qquad(\min )^{*}\end{array}$ & $\begin{array}{l}\text { Collapse time } 2 \mathrm{~mL} \\
(\mathrm{~min})^{*}\end{array}$ \\
\hline 1 & 150 & 14.0 & $2.78 \times 10^{-2}$ & 17.5 & 125 \\
\hline 2 & 55 & 8.0 & $2.22 \times 10^{-2}$ & 63.5 & 220 \\
\hline 3 & 55 & 11.5 & $4.26 \times 10^{-2}$ & 27.5 & 157 \\
\hline 4 & 90 & 94.0 & $0.37 \times 10^{-2}$ & 58.5 & 235 \\
\hline 5 & 140 & 9.0 & $5.71 \times 10^{-2}$ & 57.5 & 110 \\
\hline 6 & 150 & 1.3 & $4.88 \times 10^{-2}$ & 41.8 & 60 \\
\hline 7 & 60 & 16.7 & $1.56 \times 10^{-2}$ & 11.5 & 101 \\
\hline 8 & 70 & 52.0 & $0.91 \times 10^{-2}$ & 10.8 & 45 \\
\hline 9 & 250 & 8.5 & $7.27 \times 10^{-2}$ & 100.0 & 150 \\
\hline 10 & 260 & 15.5 & $2.94 \times 10^{-2}$ & 111.0 & 135 \\
\hline 11 & 200 & 13.0 & $3.85 \times 10^{-2}$ & 146.5 & 155 \\
\hline 12 & 85 & 20.6 & $1.67 \times 10^{-2}$ & 115.2 & 162 \\
\hline 13 & 150 & 15.0 & $3.28 \times 10^{-2}$ & 26.5 & 107 \\
\hline 14 & 120 & 15.5 & $2.76 \times 10^{-2}$ & 15.5 & 123 \\
\hline 15 & 110 & 16.0 & $3.00 \times 10^{-2}$ & 17.0 & 115 \\
\hline
\end{tabular}

${ }^{*}$ Mean \pm SD $\%$ less of $10 \%$ for foam overrun and drainage stability parameters of at least two replicates.

FO (\%): foam overrun

Lag time drain.: time to start the foam drainage.

$K_{\mathrm{dr}}: 1 /$ time required to drainage $20 \%$ of total possible.

Lag time to collapse: time required to start the collapse

Collapse time $2 \mathrm{~mL}$ : time required to decrease in $2 \mathrm{~mL}$ the height of the initial foam.

Authors of [22] have found similar results by using this polysaccharide on foams made from $\beta$-lactoglobulin, native and denatured soy protein. It was shown that $\kappa \mathrm{C}$ addition decreased foam expansion, because air incorporation was limited by increasing the viscosity of the solutions.

Multiple regression analysis has been done for foaming parameters. The regression coefficients obtained are showed in Table 3.
In most cases $R^{2}$ resulted with a good fit and the "lack of fit" resulted nonsignificant which means that the model could explain the $80 \%$ of observed responses. In other cases, "lack of fit" resulted significant which means that the order of the regression was not secondary (the model may not include all appropriate functions of independent variables or the experimental region may be too large for a quadratic model that was used). However, when a large amount of data 
TABLE 3: Model coefficients estimated by multiple linear regression for foaming properties.

\begin{tabular}{|c|c|c|c|c|c|}
\hline & $\mathrm{FO}$ & lag time to drainage & $K_{\mathrm{dr}}$ & lag time to collapse & Collapse time $2 \mathrm{~mL}$ \\
\hline Constants & 125.278 & 13.177 & 0.0305 & 13.415 & 116.956 \\
\hline \multicolumn{6}{|l|}{ Linear } \\
\hline HSP & $-51.658^{* *}$ & $27.212^{*}$ & $(-0.0034)$ & $13.297^{*}$ & $34.321^{*}$ \\
\hline $\mathrm{E} 4 \mathrm{M}$ & $(5.997)$ & $11.433^{*}$ & $(-0.0035)$ & $-3.692^{*}$ & $11.561^{* *}$ \\
\hline$\kappa \mathrm{C}$ & $-81.669^{*}$ & $11.802^{*}$ & $(-0.0001)$ & $-39.449^{*}$ & $-22.629^{*}$ \\
\hline \multicolumn{6}{|l|}{ Quadratic } \\
\hline $\mathrm{HSP}^{2}$ & $(6.233)$ & $19.088^{*}$ & $(0.0011)$ & $12.016^{*}$ & $(-9.472)$ \\
\hline $\mathrm{E} 4 \mathrm{M}^{2}$ & $(-69.783)$ & $(-2.718)$ & $(0.0017)$ & $33.244^{*}$ & $72.986^{*}$ \\
\hline$\kappa \mathrm{C}^{2}$ & $83.312^{*}$ & $9.666^{*}$ & $0.0235^{*}$ & $99.748^{*}$ & $(1.663)$ \\
\hline \multicolumn{6}{|l|}{ Interactions } \\
\hline$(\mathrm{HSP}) \times(\mathrm{E} 4 \mathrm{M})$ & $(3.109)$ & $53.219^{*}$ & $0.0356^{*}$ & $56.760^{*}$ & $94.831^{*}$ \\
\hline$(\mathrm{HSP}) \times(\kappa \mathrm{C})$ & $(9.192)$ & $14.356^{*}$ & $0.0247^{* *}$ & $-23.927^{*}$ & $-56.965^{*}$ \\
\hline$(\mathrm{E} 4 \mathrm{M}) \times(\kappa \mathrm{C})$ & $(-13.323)$ & $(0.884)$ & $0.0593^{*}$ & $-83.168^{*}$ & $-86.715^{*}$ \\
\hline$R^{2}$ & 0.964 & 0.852 & 0.8965 & 0.839 & 0.872 \\
\hline Lack of fit & NS & $*$ & NS & $*$ & $*$ \\
\hline
\end{tabular}

HSP: hydrolyzed soy protein at 4\% DH; E4M: hydroxypropyl methylcellulose; $\kappa \mathrm{C}$ : kappa-carrageenan.

${ }^{*}$ Significant value at $P<0.05 ;{ }^{* *}$ significant value at $P<0.01 ;()$ nonsignificant value.

Reduced equations for foaming properties:

$\mathrm{FO}=125.278-51.685 \mathrm{HSP}-81.669 \kappa \mathrm{C}+83.312 \kappa \mathrm{C}^{2}$

$\mathrm{Lag}$ time to drainage $=13.177+27.212 \mathrm{HSP}+11.433 \mathrm{E} 4 \mathrm{M}+11.802 \kappa \mathrm{C}+19.088 \mathrm{HSP}^{2}+9.666 \kappa \mathrm{C}^{2}+53.219 \mathrm{HSP} \times \mathrm{E} 4 \mathrm{M}+14.356 \mathrm{HSP} \times \kappa \mathrm{C}$

$K_{\mathrm{dr}}=0.0305+0.0235 \kappa \mathrm{C}^{2}+0.0356 \mathrm{HSP} \times \mathrm{E} 4 \mathrm{M}+0.0247 \mathrm{HSP} \times \kappa \mathrm{C}+0.0593 \mathrm{E} 4 \mathrm{M} \times \kappa \mathrm{C}$

$\mathrm{Lag}$ time to collapse $=13.415+13.297 \mathrm{HSP}-3.692 \mathrm{E} 4 \mathrm{M}-39.449 \kappa \mathrm{C}+12.016 \mathrm{HSP}^{2}+33.244 \mathrm{E}^{2} \mathrm{M}^{2}+99.748 \kappa \mathrm{C}^{2}+56.760 \mathrm{HSP} \times \mathrm{E}^{2} \mathrm{M}-23.927 \mathrm{HSP} \times \kappa \mathrm{C}-$ $83.168 \mathrm{E} 4 \mathrm{M} \times \kappa \mathrm{C}$

Collapse time $2 \mathrm{~mL}=116.956+34.321 \mathrm{HSP}+11.561 \mathrm{E} 4 \mathrm{M}-22.629 \kappa \mathrm{C}+72.986 \mathrm{E} 4 \mathrm{M}^{2}+94.831 \mathrm{HSP} \times \mathrm{E} 4 \mathrm{M}-56.965 \mathrm{HSP} \times \kappa \mathrm{C}-86.715 \mathrm{E} 4 \mathrm{M} \times \kappa \mathrm{C}$.

was included in the analysis, a model with significant lack of fit could still be used [23].

For $\mathrm{FO}$, a significant linear variable for $\kappa \mathrm{C}$ was observed. The negative regression coefficient points out that the $\kappa \mathrm{C}$ addition to foam measured at $60^{\circ} \mathrm{C}$ conduces to a FO decrease, as was seen before Table 2 . The largest value indicated that it was the most important variable influencing FO. The positive value of the quadratic coefficient for $\kappa \mathrm{C}$ points out that FO presents a minimum in the response.

A significant negative linear coefficient corresponding to HSP was also observed, which indicates a decrease of FO when HSP was present.

It was also demonstrated that a decrease in foam expansion at high concentrations is believed to correspond to reduced solubility of protein solutions [24]. In the other way, interaction effects between variables have been detected. Concerning lag time for foam drainage, a significant influence of every component at heating conditions was observed.

The positive regression coefficients for HSP, E4M, and $\kappa \mathrm{C}$ indicate that, in increasing concentrations of these components, the response increases and HSP presented a major influence. The positive quadratic coefficients of HSP and $\kappa \mathrm{C}$ indicate a minimum presence in the response.

Synergistic interaction effects between HSP $\times$ E4M and $\mathrm{HSP} \times \kappa \mathrm{C}$ were also observed, stronger in the first case. Tolstoguzov [25] has studied different effects on the interactions between proteins and polysaccharides. Under these experimental conditions of $\mathrm{pH}$ and temperatures, thermodynamic incompatibility would be favored and the effect of increasing the effective polysaccharide concentration would be the main explanation for the apparently increased foam stability of the mixed system. E4M gel formation would promote more stable foams against drainage, and HSP $\times \kappa \mathrm{C}$ would promote the stability by viscosity increase of the continuous phase.

The $K_{\mathrm{dr}}$ response did not present significant linear effects $(P<0.05)$. The positive quadratic term, resulting as a consequence of the addition of $\kappa \mathrm{C}$, indicates a minimum presence. Moreover, HSP $\times \mathrm{E} 4 \mathrm{M}, \mathrm{E} 4 \mathrm{M} \times \kappa \mathrm{C}(P<0.05)$, and $\mathrm{HSP} \times \kappa \mathrm{C}(P<0.01)$ interactions were significant, which conduce to a slightly antagonist effect by increasing the $K_{\mathrm{dr}}$.

In relation to the lag time for foam collapse, HSP showed a positive linear effect, increasing it by HSP addition, whereas the presence of $\mathrm{E} 4 \mathrm{M}$ and $\kappa \mathrm{C}$ decreased strongly this response.

The positive quadratic coefficients of three components indicate a minimum presence as a consequence of their addition.

A synergistic interaction between HSP $\times$ E4M which induces a lag time for foam collapse increase at heating can be also observed. At the same time, HSP $\times \kappa \mathrm{C}$ and $\mathrm{E} 4 \mathrm{M} \times \kappa \mathrm{C}$ resulted as antagonist interactions by decreasing this response. Moreover, it can be observed that $\kappa \mathrm{C}$ may provoke an increment of lag time to collapse. This indicates an unfavorable effect of $\kappa \mathrm{C}$ on this parameter in its molten state at $70^{\circ} \mathrm{C}$, whereas HSP tended to favor the lag time to collapse by increasing it strongly. These results confirm that the types of interactions at heating conditions that conduce to 


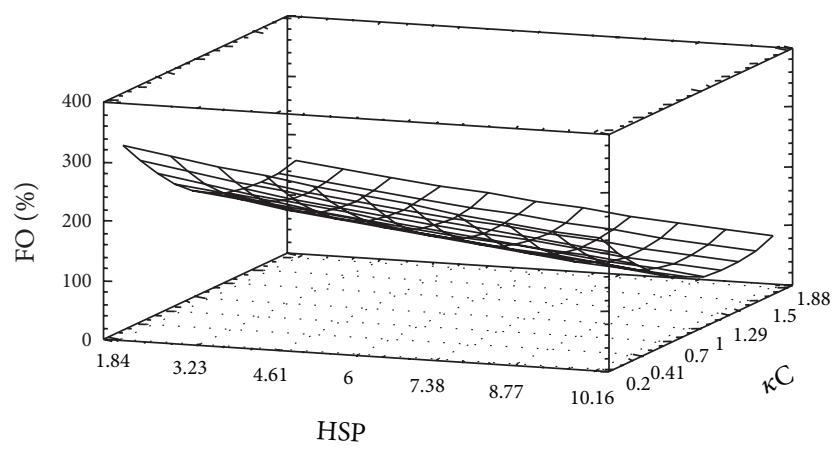

Figure 1: Foam overrun (FO) of foams corresponding to response surface plot as a function of concentration of HSP and $\kappa \mathrm{C}$ in a concentration of E4M at central point replication (1\%wt/wt). HSP: hydrolyzed soy protein at $4 \% \mathrm{DH}$; E4M: hydroxypropyl methylcellulose; $\kappa \mathrm{C}$ : kappa-carrageenan.

drainage or collapse process are very different [2]. Evidently, molten $\kappa \mathrm{C}$ presence would not favor the $\mathrm{E} 4 \mathrm{M}$ gelation, which may be essential for collapse process of foams.

With reference to the time for collapse $2 \mathrm{~mL}$ of foams, it was found that HSP and $\kappa \mathrm{C}$ showed linear effects on this response at heating $(P<0.05)$. The negative and positive coefficients values for HSP and $\kappa \mathrm{C}$ indicate an increase and a decrease of this response by addition of each one respectively. A positive linear effect $(P<0.01)$ due to E4M addition, which means that this polysaccharide produces an increase of this response can be also observed.

E4M showed as well a positive quadratic effect, indicating a minimum presence. Interaction effects between all components studied were observed. HSP $\times$ E4M interaction showed synergistic effects (positive value), whereas $\mathrm{HSP} \times \kappa \mathrm{C}$ and $\mathrm{E} 4 \mathrm{M} \times \kappa \mathrm{C}$ presented antagonist interactions, decreasing the collapse time at heating with their combinations. At difference of the lag time to drainage and the $K_{\mathrm{dr}}$ (where different results were obtained with the polysaccharide addition), the lag time for foam collapse and collapse for $2 \mathrm{~mL}$ had the same tendency.

E4M was kept constant at the central point value to generate the responses surfaces and contour lines plots for all responses studied.

Figure 1 shows the response surface plot for FO and indicates that the highest FO was obtained when HSP and $\kappa \mathrm{C}$ were in low concentrations. This behavior points out the great significance of $\kappa \mathrm{C}$ in the decrease of $\mathrm{FO}$ as stated before. However, comparing with HSP alone (2\% (wt), FO: 200\%) it can be seen that the components concentrations could be extent to higher values to obtain foams with a reasonable $\mathrm{FO}$ with these mixed systems.

Figure 2 shows the response surface for lag time to drainage of foams at heating conditions. This response was significantly influenced by HSP and $\kappa \mathrm{C}$ simultaneously.

Figure 3 shows the response surface plot for drainage rate of foams, $K_{\mathrm{dr}}$. Drainage rate is minima in a high range of HSP and $\kappa \mathrm{C}$ combinations. On the basis on their regressions coefficients, $\kappa \mathrm{C}$ is a higher significant variable than HSP on the $K_{\mathrm{dr}}$. However, this parameter did not show a relevant

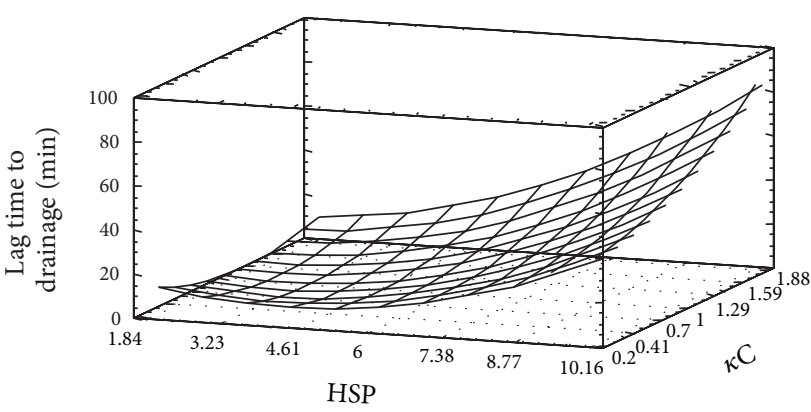

FIGURE 2: Lag time to drainage of foams corresponding to response surface plot as a function of concentration of HSP and $\kappa \mathrm{C}$ in a concentration of E4M at central point replication (1\%wt/wt). HSP: hydrolyzed soy protein at $4 \% \mathrm{DH}$; E4M: hydroxypropyl methylcellulose; $\kappa$ C: kappa-carrageenan.

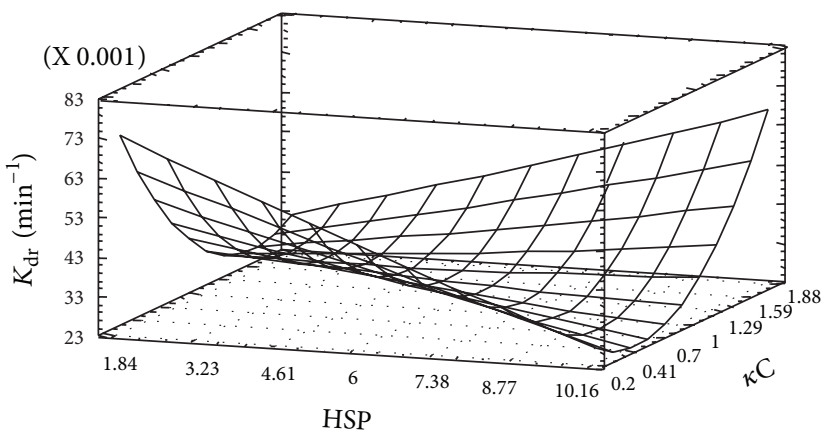

FIGURE 3: Drainage rate $\left(K_{\mathrm{dr}}\right)$ of foams corresponding to response surface plot as a function of concentration of HSP and $\kappa \mathrm{C}$ in a concentration of E4M at central point replication (1\%wt/wt). HSP: hydrolyzed soy protein at $4 \% \mathrm{DH}$; E4M: hydroxypropyl methylcellulose; $\kappa \mathrm{C}$ : kappa-carrageenan.

significance on foaming behavior as its lag time to drainage showed (Figure 2). The response showed strong variations with concentrations increase, becoming consequently in a more appropriate drainage index of foams at $70^{\circ} \mathrm{C}$. That conclusion was made on the basis of that 80 minutes for lag time to drainage may be enough to heat the mixed system without the drainage taking place. As a result, the $K_{\mathrm{dr}}$ would not be so relevant in this context.

Figure 4 shows the response surface plot for the lag time to collapse of foams at heating. Principally, HSP increased this response and $\kappa \mathrm{C}$ decreased it. The response strongly decreases when $\kappa \mathrm{C}$ is in increasing concentration value and it intensifies at high HSP concentrations.

Since the lag time to collapse of the HSP alone (2\% (wt)) was 1.3 minutes, it would be said that the polysaccharides addition would always produce stabilization against the collapse start, which is very important for systems that go through heating process.

Figure 5 shows the response surface plot for the collapse time $2 \mathrm{~mL}$ of the initial foams at heating. It can be seen that the effect of the addition of each component depends on the others concentrations, denoting a big kind of interactions between them. Thus, at low HSP concentration, 


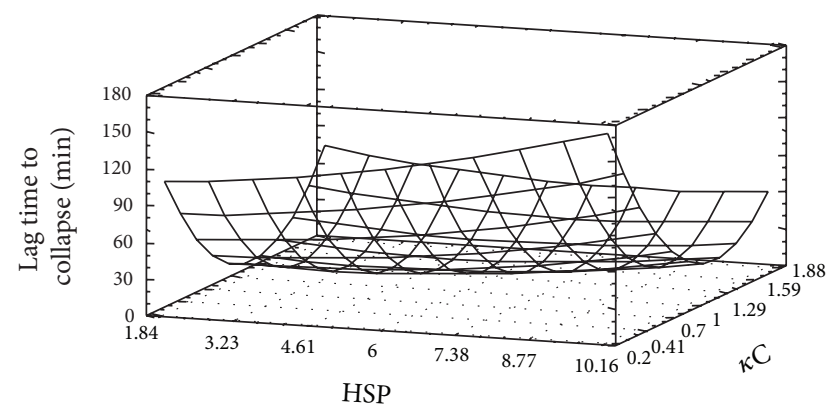

Figure 4: Lag time to collapse of foams corresponding to response surface plot as a function of concentration of HSP and $\kappa \mathrm{C}$ in a concentration of E4M at central point replication (1\%wt/wt). HSP: hydrolyzed soy protein at $4 \% \mathrm{DH}$; E4M: hydroxypropyl methylcellulose; $\kappa$ C: kappa-carrageenan.

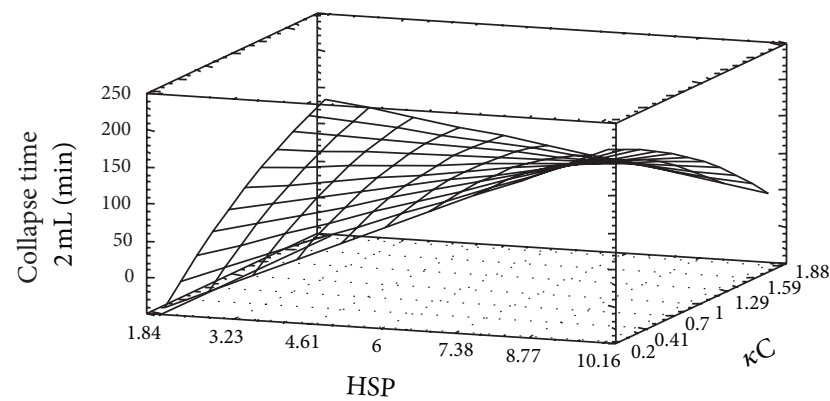

FIGURE 5: Collapse time to $2 \mathrm{~mL}$ of foams corresponding to response surface plot as a function of concentration of HSP and $\kappa \mathrm{C}$ in a concentration of $\mathrm{E} 4 \mathrm{M}$ at central point replication $(1 \% \mathrm{wt} / \mathrm{wt})$. HSP: hydrolyzed soy protein at $4 \% \mathrm{DH}$; E4M: hydroxypropyl methylcellulose; $\kappa$ C: kappa-carrageenan.

the $\kappa \mathrm{C}$ increasing concentration produces an increment of the collapse time, whereas, in high HSP concentration, the increasing $\kappa \mathrm{C}$ concentration promotes a decrease of this response.

As well as for the lag time to drainage, the results obtained showed that the times attained were enough to an eventual thermal treatment of the foam without the start of the foam collapse.

Therefore, the best combination for an increase of the collapse time resulted in a low $\kappa \mathrm{C}$ and high HSP concentrations.

\section{Conclusions}

It can be concluded that the role of polysaccharides in a combined way with a limited hydrolyzed soy proteins is fundamental to generate foams with a considerable stability against the liquid drainage and collapse of the foam over heating conditions, keeping a good foam capacity.

The huge stability increase at high temperatures was ascribed to a combined effect between the gelling character of $\mathrm{E} 4 \mathrm{M}$ at $70^{\circ} \mathrm{C}$ and the interaction with $\kappa \mathrm{C}$, which provides viscosity to the system. In a parallel work [26], we demonstrated that $\mathrm{E} 4 \mathrm{M}$ is the principal component which determines the elastic and viscoelastic characteristics of continuous phase of complex mixture at $70^{\circ} \mathrm{C}$, due to the gelled structure produced at heating process. Moreover, $\kappa \mathrm{C}$ is not gelled at this temperature and would impart viscosity to the system at $70^{\circ} \mathrm{C}$.

Synergistic interactions between protein and polysaccharides influence the foaming properties at heating. From the study, two important interactions were observed: HSP $\times$ $\mathrm{E} 4 \mathrm{M}$ and HSP $\times \kappa \mathrm{C}$. In the first case, under these conditions, thermodynamic incompatibility conduced to effective concentration of polysaccharide increas which would be the principal factor of foam stability. However, as it was stated, lag times to drainage and collapse of foams resulted in decisive parameters for foaming properties in these conditions. As a result, HSP $\times \kappa \mathrm{C}$ interactions would establish the foaming performance.

From these analyses it can be determined which concentrations would be used to optimize the foaming properties. The most significant components were HSP and $\kappa \mathrm{C}$. The HSP concentration should be high $(>7 \%(\mathrm{wt}))$ and $\kappa \mathrm{C}$ should be in a low concentration (lower than $0.7 \%(w t)$ ) to formulate a foam with enough lag times of drainage and collapse that allow heat process without foam overrun decrease.

\section{Conflict of Interests}

There is no conflict of interests of any kind regarding the publication of this article.

\section{Acknowledgments}

This research was supported by CYTED through Project A.1.2., Universidad de Buenos Aires, Agencia Nacional de Promoción Científica y Tecnológica (PICT 2008-1901) and Consejo Nacional de Investigaciones Científicas y Técnicas de la República Argentina.

\section{References}

[1] P. Vohra and F. H. Kratzer, Evaluation of Soybean Meal Determines Adequacy of Heat Treatment, Feedstuffs, Bloomington, Minn, USA, 1991.

[2] J. E. Kinsella, "Functional properties of soy proteins," Journal of the American Oil Chemists' Society, vol. 56, no. 3, pp. 242-258, 1979.

[3] S. Utsumi, Y. Matsumura, and T. Mori, "Structure-function relationships of soy protein," in Food Proteins and Their Applicationsby, S. Damodaran and A. Paraf, Eds., chapter 9, pp. 257292, Marcel Dekker, 1997.

[4] J. R. Wagner and J. Guéguen, "Surface functional properties of native, acid-treated, and reduced soy glycinin. 1. Foaming properties," Journal of Agricultural and Food Chemistry, vol. 47, no. 6, pp. 2173-2180, 1999.

[5] M. Yu and S. Damodaran, "Kinetics of destabilization of soy protein foams," Journal of Agricultural and Food Chemistry®, vol. 39, no. 9, pp. 1663-1667, 1991.

[6] S. H. Kim and J. E. Kinsella, "Surface active properties of food proteins: effects of reduction of disulfide bonds on a film properties and foam stability of glycinin," Journal of Food Science, vol. 52, no. 1, pp. 128-131, 1987. 
[7] M. Liu, D.-S. Lee, and S. Damodaran, "Emulsifying properties of acidic subunits of soy 11S globulin," Journal of Agricultural and Food Chemistry, vol. 47, no. 12, pp. 4970-4975, 1999.

[8] J. B. German, T. E. O’Neill, and J. E. Kinsella, "Film forming and foaming behavior of food proteins," Journal of the American Oil Chemists' Society, vol. 62, no. 9, pp. 1358-1366, 1985.

[9] G. Pusky, "Modification of functional properties of soy proteins by proteolytic enzyme treatment," Journal of the American Association of Cereal Chemistry, vol. 52, pp. 655-664, 1975.

[10] S. H. Kim and J. E. Kinsella, "Surface activity of food proteins: relationships between surface pressure development, viscoelasticity of interfacial films and foam stability of bovine serum albumin," Journal of Food Science, vol. 50, no. 6, pp. 1526-1530, 1985.

[11] L. Were, N. S. Hettiarachchy, and U. Kalapathy, "Modified soy proteins with improved foaming and water hydration properties," Journal of Food Science, vol. 62, no. 4, pp. 821-850, 1997.

[12] J. M. Chobert, M. Z. Sitohy, and J. R. Whitaker, "Solubility and emulsifying properties of caseins modified enzymatically by Staphylococcus aureus V8 protease," Journal of Agricultural and Food Chemistry, vol. 36, no. 1, pp. 220-224, 1988.

[13] L. S. Don, A. M. R. Pilosof, and G. B. Bartholomai, "Enzymatic modification of soy protein concentrates by fungal and bacterial proteases," Journal of the American Oil Chemists Society, vol. 68, no. 2, pp. 102-105, 1991.

[14] N. Bombara, M. C. Añón, and A. M. R. Pilosof, "Functional properties of protease modified wheat flours," Lebensmittel Wissenschaft und-Technologie, vol. 30, no. 5, pp. 441-447, 1997.

[15] J. Vioque, R. Sánchez-Vioque, A. Clemente, J. Pedroche, and F. Millán, "Partially hydrolyzed rapeseed protein isolates with improved functional properties," Journal of the American Oil's Chemists Society, vol. 77, no. 4, pp. 447-450, 2000.

[16] E. Dickinson, "Hydrocolloids at interfaces and the influence on the properties of dispersed systems," Food Hydrocolloids, vol. 17, no. 1, pp. 25-39, 2003.

[17] D. H. Doehlert, "Uniform shell desing," Journal of the Royal Statistical Society, vol. 19, no. 3, pp. 231-239, 1970.

[18] V. Zylberman and A. M. R. Pilosof, "Relationship between the glass transition, molecular structure and functional stability of hydrolyzed soy proteins," in Amorphous Food and Pharmaceutical Systems, H. Levine, Ed., pp. 158-168, Royal Society of Chemistry, London, UK, 2002.

[19] F. C. Church, H. E. Swaisgood, D. H. Porter, and G. L. Catignani, "Spectrophotometric assay using o-phthaldialdehyde for determination of proteolysis in milk and isolated milk proteins," Journal Dairy Science, vol. 66, no. 6, pp. 1219-1227, 1983.

[20] E. Morris, D. Rees, and G. Robinson, "Cation-specific aggregation of carrageenan helices: domain model of polymer gel structure," Journal of Molecular Biology, vol. 138, no. 2, pp. 349362,1980 .

[21] D. J. Carp, G. B. Bartholomai, P. Relkin, and A. M. R. Pilosofl, "Effects of denaturation on soy protein-xanthan interactions: comparison of a whipping-rheological and a bubbling method," Colloids and Surfaces B, vol. 21, no. 1-3, pp. 163-171, 2001.

[22] D. J. Carp, R. I. Baeza, G. B. Bartholomai, and A. M. R. Pilosof, "Impact of proteins- $\kappa$-carrageenan interactions on foam properties," Lebensmittel Wissenschaft und-Technologie, vol. 37, no. 5, pp. 573-580, 2004.

[23] G. Box and N. Drapper, Empirical Model-Building and Response Surfaces, Wiley, New York, NY, USA, 1987.
[24] M. Britten and L. Lavoie, "Foaming properties of proteins as affected by concentration," Journal of Food Science, vol. 57, no. 5, pp. 1219-1222, 1992.

[25] V. B. Tolstoguzov, "Protein-polysaccharide interactions," in Food Proteins and Their Application, S. Damodaran and A. Paraf, Eds., pp. 171-198, Marcel Decker, New York, NY, USA, 1997.

[26] K. D. Martínez and A. M. R. Pilosof, "Rheology and thermal transitions of enzymatically modified soy protein and polysaccharides mixtures, of potential use as foaming agent determined by response surface methodology," Food Bioscience, vol. 3, pp. 19-28, 2013. 

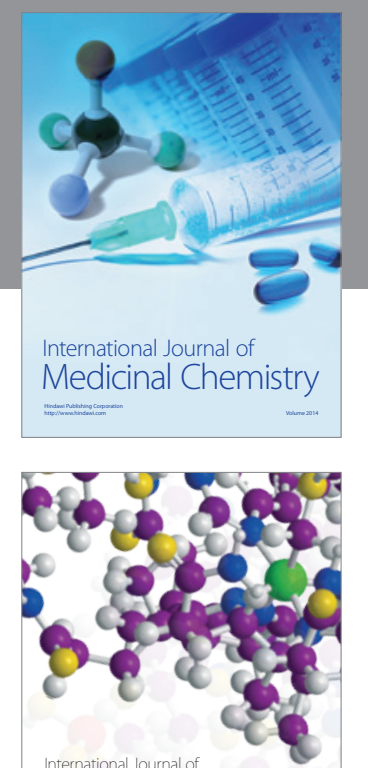

\section{Carbohydrate} Chemistry

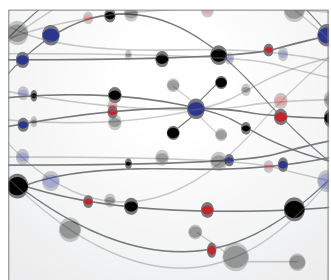

The Scientific World Journal
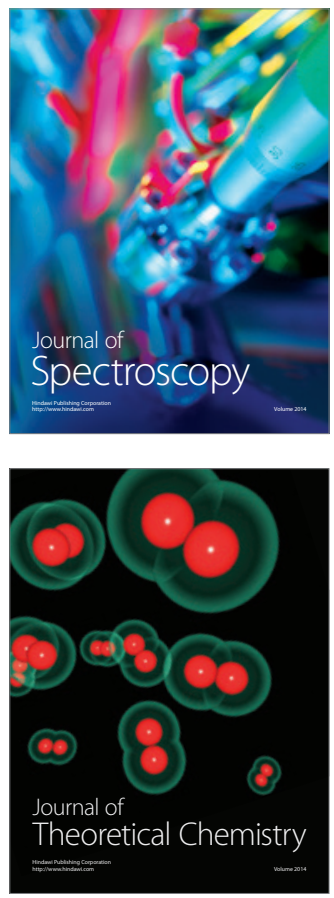
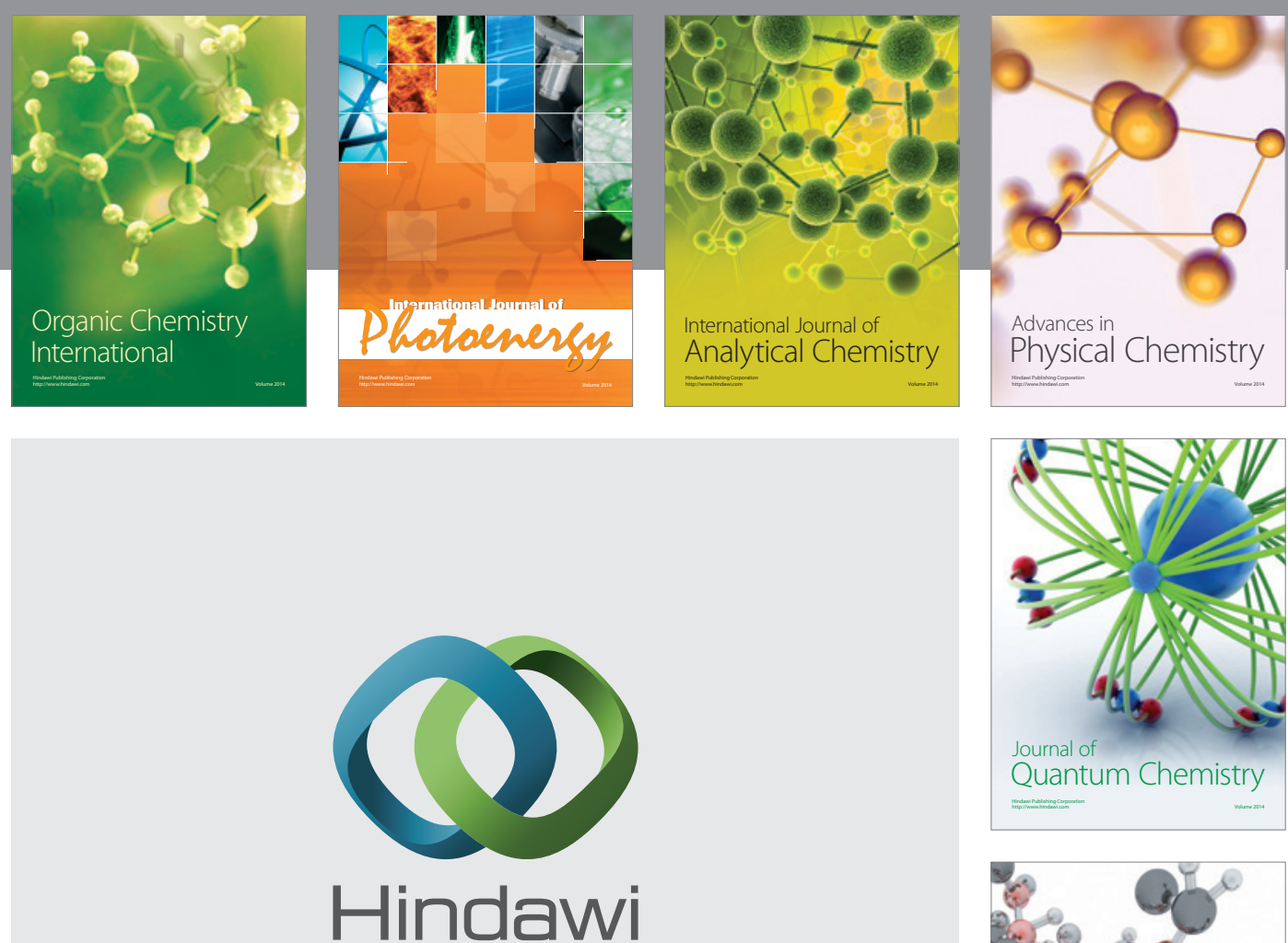

Submit your manuscripts at

http://www.hindawi.com

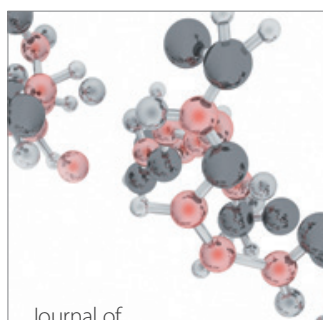

Analytical Methods

in Chemistry

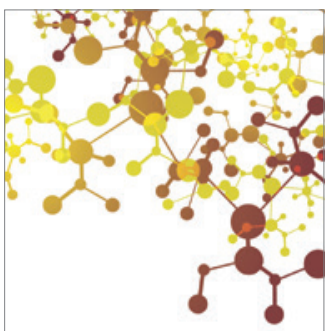

Journal of

Applied Chemistry

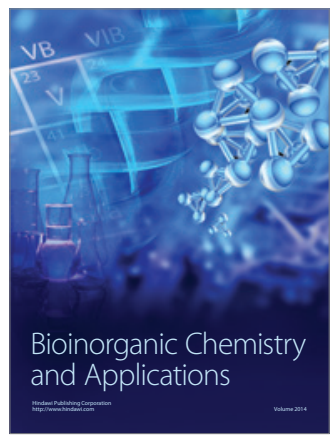

Inorganic Chemistry
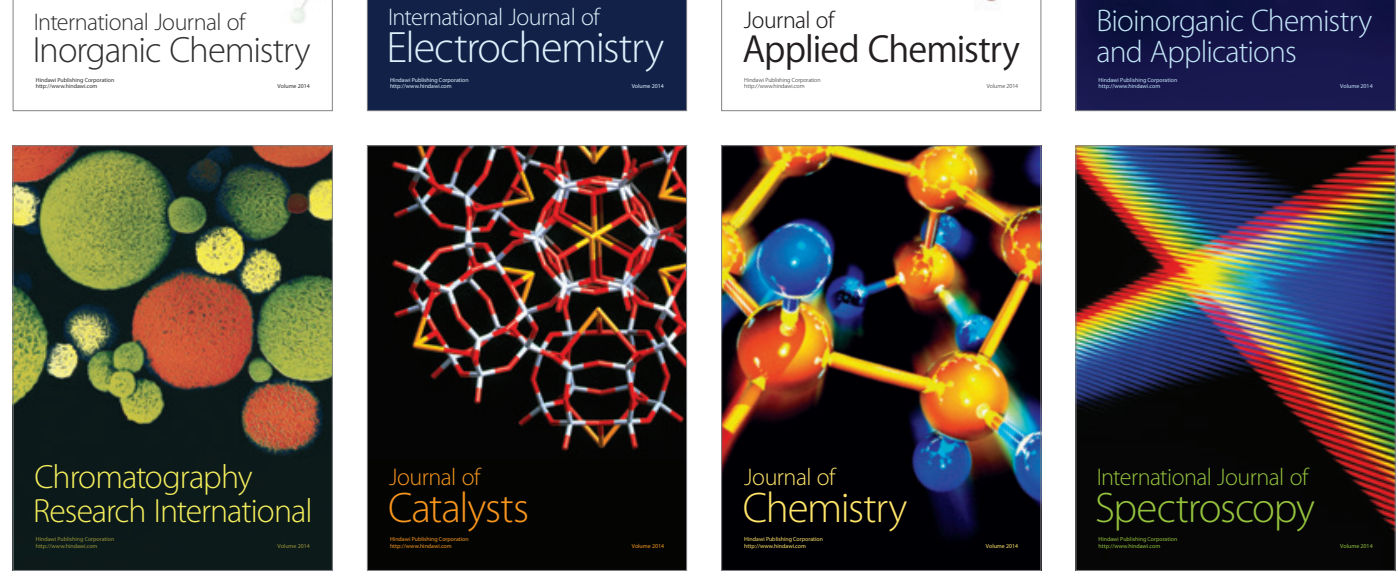